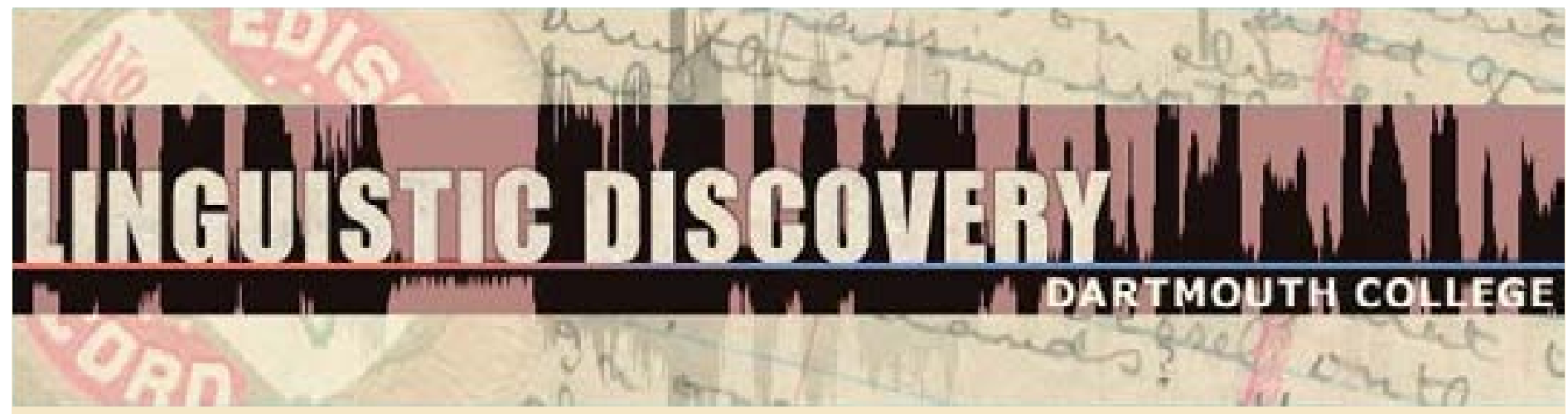

\begin{tabular}{|l|}
\hline Volume 3 \\
Issue 1 \\
2005 \\
\hline
\end{tabular}

\title{
A Typological Overview of the Seri Language
}

Stephen A. Marlett

SIL International

doi: 10.1349/PS1.1537-0852.A.282

url: http://journals.dartmouth.edu/cgi-bin/WebObjects/ Journals.woa/1/xmlpage/1/article/282

\section{Linguistic Discovery}

Published by the Dartmouth College Library Copyright to this article is held by the authors. ISSN 1537-0852 linguistic-discovery.dartmouth.edu 


\title{
A Typological Overview of the Seri Language
}

\author{
Stephen A. Marlett \\ SIL International
}

This paper presents a concise overview of some typological characteristics of Seri, a language isolate spoken in northwestern Mexico. ${ }^{1}$ Glosses are given word by word only when indicated by precise alignment; otherwise they are given phrase by phrase. ${ }^{2}$ References to various more detailed descriptive works on Seri are not indicated in the text itself; one may consult the references at the end since the titles clearly indicate the content. The data are cited in the practical orthography (see $\$ 5$ for details on the sounds).

\section{Syntactic typology}

Seri is generally head-final. This fact is reflected in various ways in the grammar as shown below and summarized in Table $1 .^{3}$

\begin{tabular}{|c|c|c|}
\hline & \multicolumn{2}{|c|}{ Table 1: Head-final characteristics of Seri } \\
\hline 1. & Dependent Clause, Main Clause & Adverbial clause precedes main clause. \\
\hline 2. & Complement $\underline{\text { Verb }}$ & Complement NP precedes verb. \\
\hline 3. & Complement Postposition & Complement NP precedes postposition. \\
\hline 4. & Clause Conjunction & $\begin{array}{l}\text { Subordinate clause precedes subordinating } \\
\text { conjunction. }\end{array}$ \\
\hline 5. & Lexical Verb, Auxiliary & Lexical verb precedes auxiliary verb. \\
\hline 6. & Noun Phrase, Noun & $\begin{array}{l}\text { Possessor noun phrase precedes possessed } \\
\text { noun. }\end{array}$ \\
\hline 7. & Material Noun & $\begin{array}{l}\text { Noun indicating material precedes head } \\
\text { noun. }\end{array}$ \\
\hline 8. & Noun Phrase, Pronoun & NP precedes pronoun in partitive expression. \\
\hline 9. & Adverb Verb & Adverb precedes verb. \\
\hline 10. & Nominal Determiner & Determiner is phrase-final. \\
\hline
\end{tabular}

First, main clauses typically follow dependent clauses (except purpose clauses).

\footnotetext{
${ }^{1}$ See the information at http://www.sil.org/mexico/seri/00i-seri.htm. Seri has been historically linked with Hokan languages, but sufficient and convincing evidence in favor of this hypothesis has not been presented (Campbell 1997s, Marlett 2001).

2 This paper is a slightly adapted version of a draft of an introductory chapter of a grammar of Seri (in preparation). The sources of the data are indicated (various texts and illustrative sentences taken from the Seri dictionary (DS2005), which also contains a short grammar written in Spanish for a general audience. Unattributed data are from personal fieldnotes. Work on the dictionary and grammar was supported in part by a grant from NSF (0010676) and has resulted in a presentation of the facts which is quite different from, for example, that of Marlett (1981). I thank Kris Waskosky, Susan Quigley and Carolyn O'Meara for their helpful comments on this paper. Sincere thanks and credit go to Mary B. Moser for the work she and her husband did in collecting a vast amount of information on the language when it was especially not easy to do so.

${ }^{3}$ Quantifiers are not included in this discussion because mosts are verbs in Seri. Adjectives are not included either because they are such an unusual category in the language; most descriptive predicates are verbs.
} 
(1)

Dependent Main

Caay cap yeen cap ipocáat $\mathrm{x}, \quad$ anxö ma saai haa hi.

(if) the horse swings its head it will injure you

'That horse is going to injure you if it swings its head.' (DS2005, ccaat)

Second, a complement (noun phrase or clause) precedes the verb to which it is related.

$\begin{array}{ll}\text { Complement } & \text { Verb } \\ \text { yeen cap } & \text { ipocáat } x, \\ \text { its face } & \text { (if) it swings it } \\ \text { '... if it swings its head, ...' (DS2005, ccaat) }\end{array}$

(3)

$\begin{array}{ll}\text { Complement } & \text { Verb } \\ \text { Hant miisaquim } & \text { ihmíimzo. } \\ \text { your sweeping the floor } & \text { I want it } \\ \text { 'I want you to sweep the floor.' (DS2005, quisaquim) }\end{array}$

(4)

$\begin{array}{lcc}\text { Subject } & \text { Complement } & \text { Verb } \\ \text { Siip cop } & \text { iionam quij } & \text { iyáaihjö. } \\ \text { the young man } & \text { his/her hat } & \text { s/he painted it red } \\ \text { 'The young man painted his hat red.' } & \text { (DS2005, caaihjö) }\end{array}$

The preceding example is also an appropriate example to illustrate the basic SOV order of constituents in the clause; the subject precedes the complement of the verb.

Third, a complement noun phrase precedes a postposition. ${ }^{4}$
Complement
Postposition
Hast ano ctam
San Esteban Island in/from man
'San Esteban Island man' (more literally, 'man in/from the mountain') (DS2005)

The preceding example also illustrates the rather rare case in Seri of a PP complement modifying a noun; as expected, the PP precedes the noun that it modifies.

Fourth, a clause precedes a conjunction to which it is related as its complement.

$\begin{array}{llr}\text { Complement } & \text { Conjunction } & \\ \text { Taapl } & \text { xox, } & \text { ihyóohit. } \\ \text { it was cold } & \text { although } & \text { I ate it } \\ \text { 'Although it was cold, I ate it.' } & \text { (DS2005, xox) }\end{array}$

Fifth, a lexical verb precedes an auxiliary verb (although auxiliary verbs are not at all similar to those of Indo-European auxiliaries).

4 This claim is complicated by other factors. Postpositions and their complements are commonly not contiguous; the complement may occur early in the sentence, but the postposition must occur very close to the verb. 

(7) Verb
Siifp
Auxiliary
will arrive
ca
teme.
'S/he says that s/he will arrive.' (DS2005, ca)

Sixth, a possessor noun phrase precedes the possessed noun.

$\begin{array}{ll}\text { Possessor } & \text { Possessed } \\ \text { [ cocázni com ] } & \text { ilít } \\ \text { the rattlesnake } & \text { its head } \\ \text { 'the rattlesnake's head ...' (DS2005, cactim) }\end{array}$

Seventh, a nominal which indicates the material from which an item is made precedes the head noun.

\begin{tabular}{|c|c|c|}
\hline (9) & $\begin{array}{l}\text { Material } \\
\text { hast } \\
\text { stone }\end{array}$ & $\begin{array}{l}\text { Noun } \\
\text { hax } \\
\text { arrow point }\end{array}$ \\
\hline
\end{tabular}

Eighth, a noun phrase (actually, a determiner phrase) precedes a pronoun to form a partitive phrase.

(10)

$\begin{array}{cl}\text { NP } & \text { Pronoun } \\ \begin{array}{l}\text { [ seaatoj tanticat ] } \\ \text { the goats }\end{array} & \begin{array}{l}\text { some } \\ \text { some of the goats }(\mathrm{DS} 2005, \mathrm{pac})\end{array}\end{array}$

Ninth, an adverb precedes a verb. ${ }^{5}$
(11) Adverb Verb
Miizj ihmiya.
well I know it
'I know it well.' (DS2005, miizj)

Tenth, a determiner is phrase-final. ${ }^{6}$
(12) Noun Determiner
caay cap
horse the
'the horse' (DS2005, ccaat)

\footnotetext{
5 This is true for the most robust adverbs. There are, in fact, a few adverbs which follow the verb.

6 The facts therefore support the head-final typology if the Determiner is taken as a head, as in the DP hypothesis (Abney 1987).
} 
Seri is a pro-drop language. Pronominal participants of a clause are typically expressed only through the agreement morphology on the verb, whether finite or non-finite (with the exception noted below), ${ }^{7}$ although an independent pronoun ${ }^{8}$ may occasionally occur for emphasis.

(13) Iyáaihjö.

'S/he painted it red.' (DS2005, caaihjö)

$\begin{array}{llll}\begin{array}{l}\text { Hehe an } \\ \text { desert area }\end{array} & \text { a from } & \begin{array}{l}\text { mota } \\ \text { s/he came there his/her coming }\end{array} & \begin{array}{l}\text { iti, } \\ \text { on }\end{array} \\ \text { haa } & \text { motat, } & \begin{array}{l}\text { itcaiilam ma, } \\ \text { there }\end{array} & \\ \text { they came } & \text { they were shooting him/her }\end{array}$

$\begin{array}{llll}\text { tooxquim, } & \text { tooxquim, } & \text { toc } & \text { cömoma. } \\ \text { s/he was shooting } & \mathrm{s} / \text { he was shooting } & \text { there } & \mathrm{s} / \text { he came }\end{array}$

'He was coming from the desert, (and) while he was coming there, they were coming, they were shooting him, he was shooting, he was shooting, he was coming there.' (Hipocampo 9)

(15) Comcáii quih him iházt ixóomzo ...

woman the to.tattoo.me s/he.wanted.it

'The woman wanted to tattoo me, ...' (DS2005, quizt)

(16) He hin yomáxpx.

1st pronoun s/he wasn't mad at me

'S/he wasn't mad at me.' (DS2005, caafin)

(17) ¡Ihpóocta!

'Look at me!' (DS2005, hpo-)

Imperative verbs do not take normal subject person inflection; they are inflected in the imperative mood.
(18) ¡Ox cmah!
thus don't do it!
c- (Imperative), m- (Negative)
'Don't do that!'

The subjects of atmospheric verbs are also non-overt.

\footnotetext{
7 The agreement morphology for objects is written in the practical orthography as a separate word; but the evidence is clear that these morphemes in question are prefixes.

8 The independent pronouns do not indicate number or case. The pronoun he, for example, can be used to refer to first person singular or plural, regardless of grammatical role in the clause.
} 
(19) Pomápca, $\quad$ hax tama. ${ }^{9}$
it will not rain I hope
'I hope it doesn't rain.' (DS2005, capca)

Pronouns are required in one situation: to express the subject of an independent clause which does not have a finite verb. The predicate is either a noun phrase without a verb, or it is a nominalized verb. And demonstrative forms are commonly used in lieu of true third person pronouns.

(20)

$\begin{array}{lll}\text { Demonstrative } & \text { Predicate NP } & \\ \text { Tiix } & \text { ctam immátiscal } & \text { iha. } \\ \text { that.one } & \text { man who is not a braggart } & \text { Decl } \\ \text { 'He isn't a braggart.' } & \text { (DS2005, cmatiscal) } & \end{array}$

(21)
Pronoun
$\mathrm{He}$
Hezitmísoj quij
ano
Nominalized Verb
I/we Hermosillo the from it one who comes Decl
'I have come from Hermosillo.' (DS2005, ano)

(22)
Pronoun
He María quih yaaco quih
halx ano
Nominalized Verb
I/we Maria's house
a bit in it one who will arrive
ha.
'I am going to visit María's house for a moment.' (DS2005, caafp)

Relative clauses (always nominalized) often appear to follow the head in Seri, but virtually all of the examples could be analyzed as head-internal relative clauses, and the rare case (such as (25) and (26)) must be so analyzed. Therefore the following examples are bracketed as if they were head-internal relatives. The head nouns are underlined. (Definite articles are often used inside the noun phrase as a kind of linking device, I believe, somewhat similar to Ezafeh, as seen in these examples and many others.)

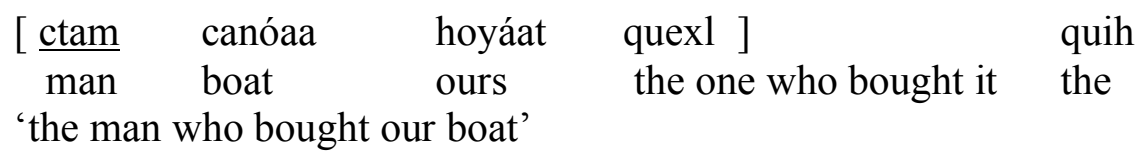

$\begin{array}{llll}\text { [ziix } & \text { quih hapáhit } & \text { quih cacáaixaj ] } \\ \text { thing the what is eaten the what gives strength }\end{array}$

'something to eat that gives strength' (DS2005, cacáaixaj)

\begin{tabular}{|c|c|c|c|}
\hline [ $\underline{\text { haaco }}$ & $\begin{array}{l}\text { caacoj } \\
\text { what is big }\end{array}$ & cazíim & $\begin{array}{l}\text { cmaa quiih ] } \\
\text { what is new }\end{array}$ \\
\hline
\end{tabular}

9 This is not easily translated literally. 
(26)

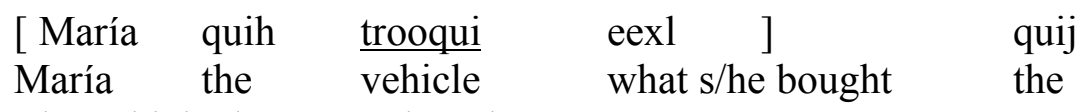

'the vehicle that María bought'

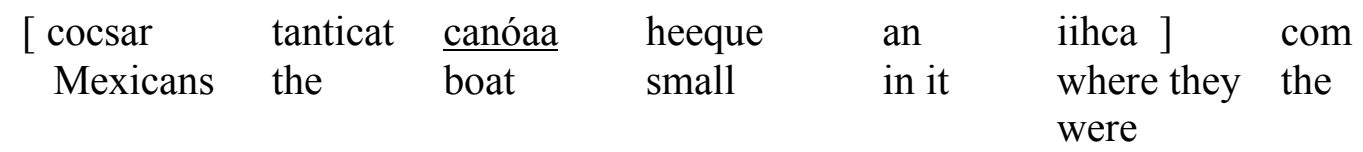

'the small boat that the non-Indian Mexicans were traveling in' (DS2005, cocpémetx)

Yes-no questions require either a verb inflected in an interrogative mood, or the question morpheme $y a$ (written as a suffix in the practical orthography) after the nominal predicate (which may be a nominalized verb). They are otherwise not distinguished syntactically from statements. A question is not well-formed solely using intonation.

¿Hax quih iiqui tpam?

with water is it swallowed?

t- (Interrogative Mood)

'Is it swallowed with water?' (DS2005, iiqui)

¿Me siitax queeya?

you one who will go Aux-Interr -ya (Interrogative)

‘Are you going to go?' (DS2005, me)

(30) ¿Hastya?

'Is it a stone?' -ya (Interrogative)

¿Ctam tiix hatéiictim zo ctaaiya?
man that one a piece of cloth one who wears a kilt - Interrogative
'Does that man wear a kilt?' (DS2005, ctaai)

A content question also requires a verb in the interrogative mood or the question morpheme $y a$. The interrogative pronoun or adverb most commonly occurs in preverbal position, although it also sometimes appears in (roughly) sentence-initial position.

Canóaa com ¿quíih $\quad$ yaaiya?
the boat who(se)? what s/he made - Interrogative
'Who made the boat?' (DS2005, caai)


(33)

Isolca quih ¿zó cyaxiya?

the beings how? one who measures - Interrogative

'How many people were there?' (DS2005, isolca)

(34)

$\begin{array}{lcc}\text { ¿Zímjöc } & \text { mizáah } & \text { cötafp? } \\ \text { when? } & \text { your day } & \text { does it arrive to it? } \\ \text { 'When was your birthday?' } & \text { (DS2005, izáah) }\end{array}$

\section{Construction typology}

This sections presents information about a variety of constructions which occur in the language. See also $\S 4$ for other constructions which are intimately linked to certain verb forms.

Seri has a passive construction which is the cross-linguistically common type in which the agent cannot be overtly expressed. The patient is the surface subject of the verb (which has passive morphology).
(35) Ihpyopázt.
p- (Passive)
'I was tattooed.'

It also has a passive construction of a much more unusual type: an impersonal passive of transitive verbs. The patient is not the surface subject of the verb, although the verb still has passive morphology. The patient looks like a direct object, although it arguably is not.

(36) Hizi yopázitim.

'We were tattooed.' (More literally, 'It was tattooed us.')

A special construction is used when the main verb is a number predicate indicating the number of times the action expressed in the complement clause occurred. The complement clause is nominalized, but the number verb is also inflected for the same person as the subject of the complement clause.

$\begin{array}{ll}\text { [ Haptco miimalim quih ] } & \text { inyaháatxo. } \\ \text { your already looking at it } & \text { you ... many times }\end{array}$

'You have already looked at it many times.' (DS2005, caháatxo)

Two verbs (quimzo 'want' and quiya 'know (how)') may take complement "clauses." The complement clauses are always either infinitival or "nominalized," never finite.

$\begin{array}{lcl}\text { Comcáii quih } & \text { [ him iházt }] & \text { ixóomzo ... } \\ \text { the woman } & \text { to tattoo me } & \text { s/he wanted it } \\ \text { 'The woman wanted to tattoo me, ...' } & \text { (DS2005, quizt) }\end{array}$


(39)

Hant miisaquim ihmíimzo.

your sweeping the floor I want it

'I want you to sweep the floor.' (DS2005, quisaquim)

(40)

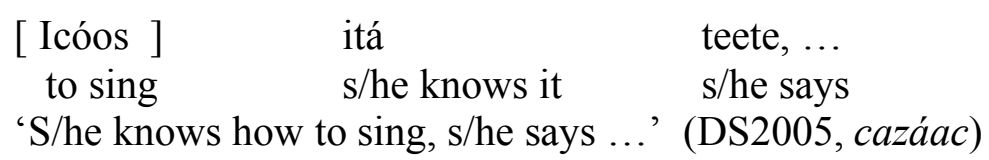

The verb quixi 'finish' is simply juxtaposed to a clause whose verb is in dependent clause morphology and whose subject is coreferential with its subject.
Iscám
com itáacöim
itáxi, ...
his/her reed boat the
$\mathrm{s} /$ he readied it
$\mathrm{s} /$ he finished it
'S/he finished readying her/his reed boat, ...' (DS2005, caacöim)

Reflexive clauses are transitive clauses with an inflected reflexive pronoun that is 'one's being or body'.
Zaaj $\mathrm{z}$ an
hisoj
ihyísxö.
in a cave
myself I hid it
'I hid in a cave.' (DS2005, isoj, quiisxö)

Reciprocal clauses are transitive clauses with the adverb pti and a verb that has some characteristics of singularity as well as plurality. The stem -azitim in the following example is the singular subject, multiple action form; compare -azt (singular subject, simple action), -azto (plural subject, simple action), and -azitam (plural subject, multiple action). ${ }^{10}$
Pti iyóozitim.
each other $\quad \mathrm{s} /$ he tattooed $\mathrm{him} / \mathrm{her}$
'They tattooed each other.' (DS2005, pti)

Seri utilizes switch-reference marking on dependent clauses. The morphemes $t a$ and $m a$ follow dependent future and dependent past clauses (respectively) to indicate that the subject of one clause is not coreferential with the subject of the next clause. There is no overt marking of coreferentiality. The key point of Farrell, Marlett and Perlmutter (1991) was to show that the notion of subject relevant to this construction is not the common one.

Moosni hatíin pac ihpamótjö, ihpáatj ta, hasíitoj aha.

I will tenderize some dry turtle meat I will pound it we will eat it

'I am going to tenderize this dry sea turtle meat by pounding it, and we will eat it.'

(DS2005, caatj)

10 The transitivity of the construction is not provable from the simple examples, but there are ways to make this evident. 
(45) Sahmées caacöl pac he tamlajc ma, ano hmeemjöc. they brought me some oranges I peeled them

'They brought me some oranges, (and) I peeled them.' (DS2005, queemoz)

(46) He hptahahásaquim ma $\mathrm{x}$ ihxoquéepe. my hair is combed I like it

'I like it when my hair is combed.' (DS2005, ah-)

In the preceding example, the subject marking on both clauses is first person singular. (The first verb is the passive form of a transitive verb -ahásaquim meaning 'comb the hair of someone', which is the causative form of the intransitive lexical reflexive verb-asaquim 'comb one's own hair'. Part of the reason for which different subject marking occurs in the first clause is the fact that the underlying subject (Agent) of the first clause is not coreferential with the underlying subject (Experiencer) of the second clause.

\section{Morphological typology}

In some key ways, Seri is a head-marking language (Nichols 1986). In the clause, the verb (as head) carries person and number marking for the subject and direct object, and person marking for indirect object. The nominals (as dependents) are not marked for case at all. This is shown in the following example.

\begin{tabular}{|c|c|c|c|}
\hline Неexој & zo & $\begin{array}{l}\text { Head } \\
\text { mpaai, }\end{array}$ & m- (2s Subject) \\
\hline torch & $\mathrm{a}$ & $\begin{array}{l}\text { (if) you make it } \\
\text { Head }\end{array}$ & \\
\hline $\begin{array}{l}\text { itáaij iizc } \\
\text { beach }\end{array}$ & $\begin{array}{l}\text { tintica } \\
\text { the }\end{array}$ & compáapjö ta $x, \ldots$ & co- (3 Ind. Obj.) \\
\hline
\end{tabular}

In the possessed noun phrase, the possessed item (as head) carries person agreement with the possessor (as dependent), which is not marked for case.

$\begin{array}{clll} & \text { Head } & \\ \text { [ cocázni com ] } & \text { ilít } & \text { quij } & \text { i- (3 Possessor) } \\ \text { the rattlesnake } & \text { its head } & \text { the } & \\ \text { 'the rattlesnake's head ...'(DS2005, cactim) } & \end{array}$

Postpositional phrases have inflected postpositions as their head; their complements are not marked for case.

$\begin{array}{lll} & \text { Head } & \\ \text { ¡Miizj hoocta! } & \text { miti } & \text { hpsozám xo tax. } \\ \text { be careful! } & \text { on you } & \text { I will step } \\ \text { 'Be careful, because I might step on you.' (DS2005, cozám) } & \end{array}$


(50)

$\begin{array}{lll}\text { Complement } & \text { Head } & \text { i- (3 Possessor) } \\ \text { hant z } & \text { iti } & \\ \text { a place } & \text { on it } / \text { him } / \text { her } & \\ \text { 'somewhere' } & \text { (DS2005, caap) }\end{array}$

(51)

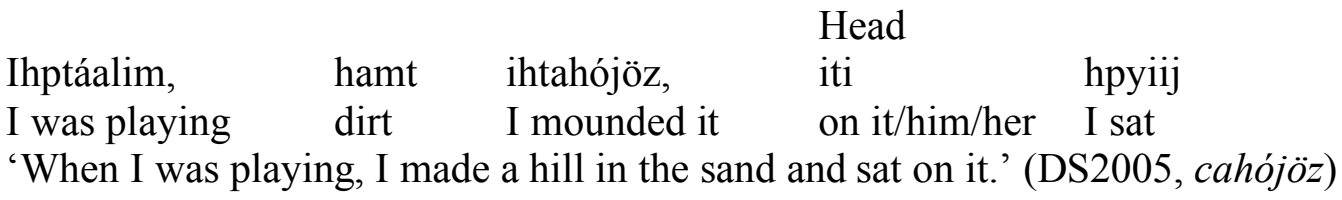

In other ways, Seri is a dependent-marking language. Subordinate clauses are clearly marked as such by special morphology, both in relativized clauses (nominalizations) and in adverbial clauses (non-final morphology and switch-reference marking).

(52) Dependent

Caay cap yeen cap ipocáat $\mathrm{x}$, po- (Dependent Future)

(if) the horse swings its head

Main

anxö ma saai haa hi.

si- (Independent Future)

it will injure you

'That horse is going to injure you if it swings its head.' (DS2005, ccaat)

(53)

$\begin{array}{ll}\text { Dependent } & \text { Dependent } \\ \ldots \text { haa } \quad \text { motat, } & \text { itcaiilam ma, } \\ \mathrm{t}-(\text { Dependent Past) } & \mathrm{t}-(\text { Dependent Past), ma (Different Subject) } \\ \text { they were shooting him/her }\end{array}$
$\begin{array}{ll}\text { there they came } & \text { they were coming, they were shooting him,...' (Hipocampo 9) }\end{array}$

Inflectional noun morphology is relatively simple. The prefixes which may occur on inalienable nouns are possessor prefixes and the absolutive (i.e., lack of possessor). There are no diminutive or augmentative forms.
mi-lít
ha-lít
2.Possessor-head
'your head'
Absolutive-head
'head'
(DS2005, ilit)
(DS2005, halit)

Suffixes which occur on nouns, along with stem modification, indicate plurality.

$$
\begin{array}{ll}
\text { hast } & \text { hasatoj, } \\
\text { 'stone' } & \text { 'stones' }
\end{array}
$$

(DS2005, hast)

$\begin{array}{llll}\text { atcz } & \text { atcal } & \text { atcalcoj } & \\ \text { 'her younger } & \text { 'her younger } & \text { 'their younger } & \text { (DS2005, atcz) } \\ \text { sister' } & \text { sisters' } & \text { sisters' } & \end{array}$


Many nominal expressions derive transparently from verbs (through prefixation) and are in common, everyday use. Some examples are:

(57) ziix icácötim

'blanket (thing that one covers up with)' (DS2005)

(58) ziix hacx tiij coos

'radio (thing that, sitting somewhere, sings)' (DS2005)

icamátj

'fever (that with which one is hot)' (DS2005)

Verbs are morphologically complex. Almost all of the inflectional and derivational morphemes are prefixes. These include the following (an incomplete list):

(60) Tense/Mood

Imperative

Person Agreement (Subject, Direct Object, Indirect Object)

Nominalizers (Subject, Object, Action/Oblique)

Negation

Passive

Unspecified Object

Causative

The most important true suffixes show number in some way (a complicated topic also discussed below) - either number of the subject (a kind of agreement), or number of the action (simple, repetitive, iterative). ${ }^{11}$

(61) -aasj

'extend (something) to dry out, singular subject' (DS2005, caasj)

-aasalim

'extend (something) to dry out repeatedly or iteratively, singular subject'

-atóoslcoj

'extend (something) to dry out, plural subject'

-atóosalam

'extend (something) to dry out repeatedly or iteratively, plural subject'

Verbs may be derived from inalienable nouns by adding the prefix $i-$; the result is a verb that means something like 'have $\mathrm{X}$ '.

-taamt

'sandal, shoe'

(DS2005, itáamt)

\author{
-i-taamt \\ 'have sandals, shoes' \\ (DS2005, quitáamt)
}

11 As can be seen by the morpheme -tóo-, infix morphology is also sometimes involved in pluralization. Another suffix, -ot, not infrequently occurs in causative verb formation, but it is not productive and it is not clear what its function is. 


$$
\begin{aligned}
& \text {-tcmajéem } \\
& \text { 'younger sister's husband' } \\
& \text { (DS2005, atcmajéem) }
\end{aligned}
$$

-i-tcmajéem

'have as brother-in-law'

(DS2005, quitcmajéem)

Other derived verb forms are described in the section below on the lexicon.

It is obvious from the above that the Seri language is synthetic rather than isolating. An intransitive verb has more than 110 different forms, and a transitive verb more than 220. Morphemes are relatively easy to segment, although there are significant exceptions, and so the language would be categorized as quite agglutinative but also fusional in some cases. The verb for sing (-oos) is an example that illustrates these facts; it is a typical intransitive verb that begins with $o$. A few forms are listed below. Only simply morpheme breaks are indicated.

(64)

c-oos
i-m-óos
c-oos-tim
as
c-m-oos
ihp-s-óos aha
ihp-sc-m-oos aha
y-as
ihp-y-ás
yo-m-óos
y-as
ih-y-as
i-c-óos
ic-óos

(one prefix)

(two prefixes)

(one prefix, one suffix)

(one prefix)

(two prefixes)

(two prefixes)

(three prefixes

${\text { (one prefix })^{12}}^{12}$

(two prefixes)

(two prefixes)

(two prefixes) $^{13}$

(two prefixes)

(two prefixes)

(one prefix) 'the one who sings'

'the one who does not sing'

'the one who sings repetitively'

'Sing!'

'Don't sing!'

'I will sing.'

'I will not sing.'

'S/he sang.'

'I sang.'

'S/he didn't sing.'

'his/her singing / song'

'my singing / song'

'one's song'

'to sing'

A significant fact about Seri morphology is the way in which suppletive allomorphs of various morphemes are conditioned by (superficial) transitivity of the clause. Intransitive clauses (those without a superficial direct object, including passive clauses) are sharply distinguished from transitive clauses (those with such a direct object). Some examples of the kind of

\begin{tabular}{|c|c|c|}
\hline & Intransitive & Transitive \\
\hline First person singular subject agreement & hp- & h- \\
\hline Infinitive & ica- & iha- (plus Ablaut) \\
\hline Imperative (before o) & (Ablaut) & h- \\
\hline First person singular restrictive & caa- & aa- \\
\hline Nonfuture action/oblique nominalizer & $y-$ & h- \\
\hline
\end{tabular}
allomorphy conditioned in this way include the following:

(before o, oo, or aa)

There is no noun incorporation of the type where noun roots combine with standard verb roots.

\footnotetext{
12 Subject agreement for third person subject is the absence of overt agreement for other persons.

13 Third person possessor is overtly marked but it is deleted phonologically before $y$.
} 


\section{Lexicon}

The Seri language has a rich lexicon; it is notable that it has not incorporated very many loanwords. The latter is due primarily to the long isolation from Spanish-speaking communities and mutual hostility between the two cultures for a long period of time.

The major word classes are verbs and nouns. Postpositions are inflected (as shown above) and look like nouns; some have singular and plural forms: hiihax 'with me', miihax 'with you' (sg.), hiicot 'with us'. Adjectives are not an important class of word in Seri (see below). Most quantifiers, including numbers, are intransitive verbs. Determiners are richly represented. The singular indefinite article, zo, is presumably related to the word for 'one', tazo. The definite articles have developed from subject nominalized verb forms of positional and motion verbs. Common determiners with their stereotypical uses are:

(66) Determiner

$\begin{array}{ll}\text { zo } & \text { 'a' } \\ \text { pac } & \text { 'some' (with count nouns or mass nouns) } \\ \text { cop } & \text { 'the' (standing, singular) } \\ \text { quij } & \text { 'the' (seated, singular) } \\ \text { com } & \text { 'the' (lying down, singular) } \\ \text { quih } & \text { 'the' (flexible; also phrase-internally for linking items, } \\ & \text { singular; also a kind of default article) } \\ \text { timoca } & \text { 'the' (approaching, singular) } \\ \text { tintica } & \text { 'the' (going away, singular) } \\ \text { tamocat } & \text { 'the' (approaching, plural) } \\ \text { tanticat } & \text { 'the' (going away, plural) } \\ \text { coi } & \text { 'the' (general plural) }\end{array}$

As in some other languages of the Americas, the verbs include facets of meaning in them that makes them difficult to translate with simple glosses. In Seri, these are meanings embedded in the roots themselves, not in some prefix that is added to a basic root. For example: caazi and cahéectim 'transport, carry'; quiip 'transport on the head', quiiztim 'transport on hip', quicséenpx and casóompx 'transport long thing under the arm', cooi 'transport in one trip', csanj 'transport person on one's back', cahásquim 'transport in boat or car', quixop 'transport with pole over the shoulder', cacáaix 'transport with pole', quizni 'transport using a handle', quizcápxla 'transport under arm'.

A noun class system is developing in the language, although at this point its origin is still quite transparent in most cases (relating to physical orientation). This noun class system is indicated by the choice of definite article. The word zaah means 'sun' and 'day'; the meanings are distinguished by the article. Whereas the noun meaning 'sun' takes the article quij as expected for a spherical object, the noun meaning 'day' takes the article cop because this has become the standard article for abstractions of various sorts.

(67) zaah quij 'the sun' (DS2005)
(68) zaah cop 'the day' (DS2005)


Adjectives are rare in Seri and it could be argued that they are morphologically-deficient verbs. The vast majority of descriptive predicates in the language are no different from intransitive predicates which are active verbs. The examples which follow are therefore not adjectives modifying nouns but rather relative clauses, identical to those presented earlier. ${ }^{14}$

cmaam

caaspoj

cop

c- (Subject Nominalizer)

woman the one who writes

the

'the woman who is writing'

(70)

cmaam

cacösxaj

cop

woman the one who is tall the

'the woman who is tall, the tall woman'

(71) cmaam

imáaspoj

i- (Subject Nominalizer in

cop

negative clauses), m- (Negative)

woman the one who does not write

the

'the woman who is not writing'

(72)
cmaam
imácösxaj
i- (Subject Nominalizer in
negative clauses), m- (Negative)
woman the one who is not tall
the
'the woman who is not tall'

Many transitive verbs have intransitive counterparts in which the patient is not expressed in the clause.

(73)
-o-cázit
'x take y away forcibly'
'x take away forcibly'

(DS2005, ccazit)

(DS2005, cocázit)

$(74)$

$\begin{array}{ll}\text {-izi } & \text {-eezi } \\ \text { 'x defeat y' } & \text { 'x defeat' } \\ (\mathrm{DS} 2005, \text { quiizi }) & \text { (DS2005, queezi) }\end{array}$

Causative verbs may be derived from simple verbs by adding one of the causative prefix (typically $a-, a c-$, or $a h-){ }^{15}$

14 The same is true for numbers; they are intransitive verbs.

15 Sometimes there is a bit more complexity involved. 


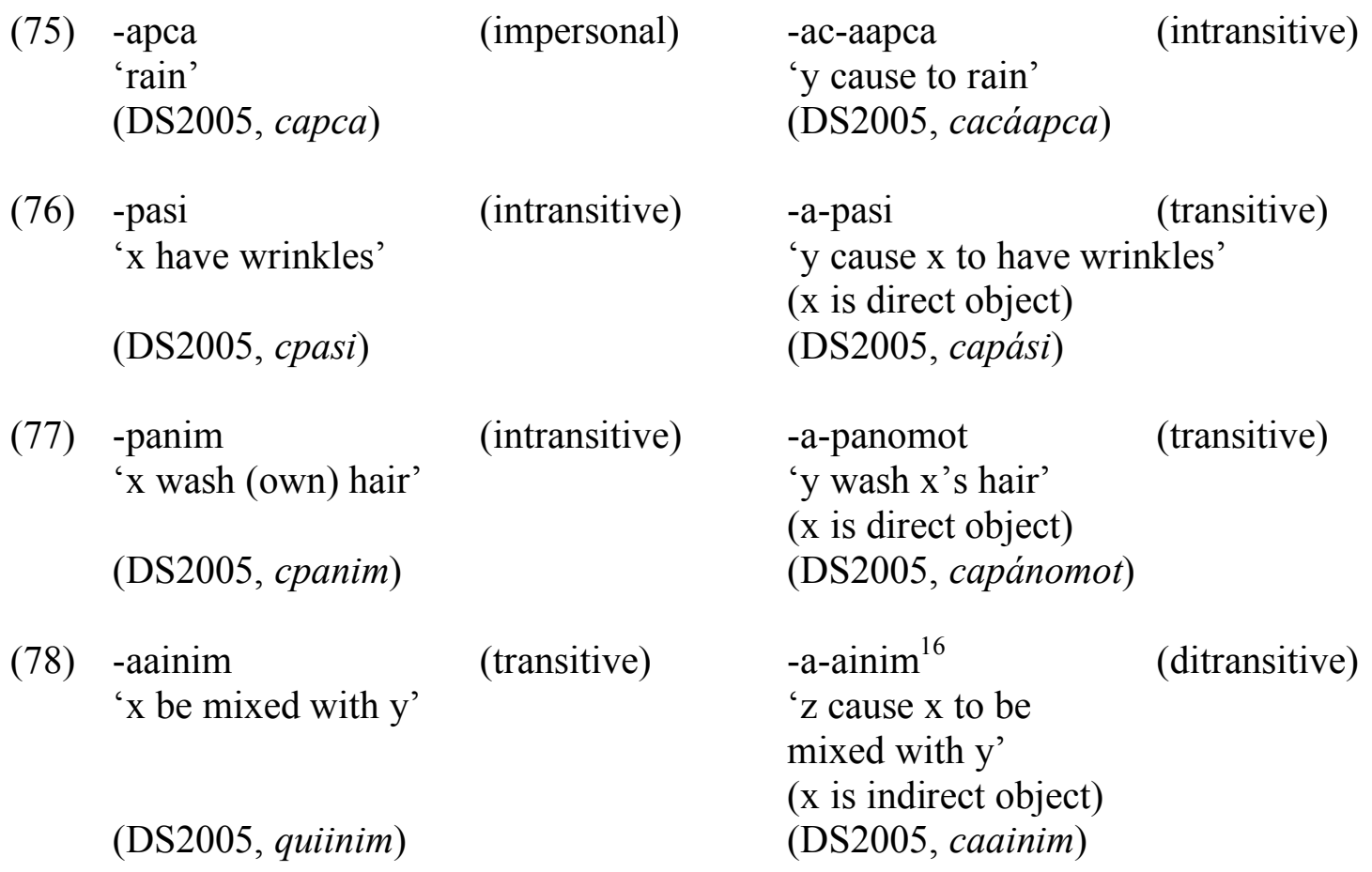

There is another kind of derived verb with virtually the same morphology as causatives; the meaning is to help someone do the action.
(79) -cazlil
' $\mathrm{x}$ mash y with teeth'
(DS2005, ccazlil)
(transitive) -a-cazatol
' $\mathrm{z}$ help $\mathrm{x}$ to mash $\mathrm{y}$ with teeth'
(transitive)
( $\mathrm{x}$ is direct object)
(DS2005, cacázatol)

And yet another kind of derived verb takes similar morphological trappings as causatives and yet is even more distinct from those. The derived verb permits the expression of an experiencer (as subject).
(80) -acat
' $\mathrm{x}$ be bitter or salty'
(intransitive)
-ac-aacat
' $\mathrm{y}$ find $\mathrm{x}$ bitter or salty'
(transitive)
( $\mathrm{y}$ is subject; $\mathrm{x}$ is direct
object)
(DS2005, cacat)
(DS2005, cacáacat)

Seri does not have complementizers nor does it have relative pronouns. It also does not have any negative words per se; negation is only marked on the verb (by a prefix).

16 The basic verb and the causative form are not identical in the way they conjugate, despite their similar presentation here. 


$\begin{array}{lclll}\ldots & \text { cmilque } & \text { zo } & \text { ma sconsácj } & \text { aha. } \\ \text { person } & \text { a } & \text { s/he will not carry you on hip } & \text { Aux-Decl } \\ & \ldots & \text { nobody is going to carry you.' (DS2005, } c \text { sacj) }\end{array}$

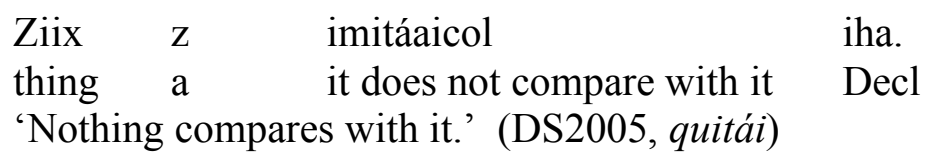

Simple demonstrative pronouns are either close (hipiix 'this one', hizáax 'these') or farther away (tiix 'that one', taax 'those'.) The complex demonstratives display a three-way distinction: proximal, medial and distal. These are formed by combining a locative expression with an article; as a result, they are rather numerous. A few examples: hipcom 'this (lying close)', hipquij 'this (sitting close)', hizcoi 'these (close)', ticop 'that (standing at a distance), himcop 'that (standing at a greater distance)'.

A clear morphological distinction exists between common nouns, kinship terms, and other inalienably possessed nouns. Only the latter two classes generally can have morphological indicators of possessors; in fact, they must have some possessor indicated or else have the absolutive prefix mentioned earlier: hipot 'my calf', mipot 'your calf', ilit 'his/her calf', hapot 'calf (of leg)'; hita 'my mother', mata 'your mother', ata 'his/her mother', hapéte 'mother'. These examples also indicate a morphological difference between kinship terms and other inalienably possessed nouns: kinship terms take a different set of possessive prefixes in second and third person ( $m a$ - for second person rather than $m i$ - which occurs for second person possessor generally) as well as a different absolutive prefix.

The kinship terminology for Seri is perhaps one of the most extensive sets attested in the world, having more than fifty primary terms. Relevant parameters include the sex of ego as well as the age and sex of the referent. Therefore, for example, nine terms exist for 'sibling', as shown in the following table. Similar patterns exist for other relationships.

Male

Younger

Female ego

Male ego

aacaz
'her younger
brother'

brother

$\begin{array}{lll} & & \begin{array}{l}\text { axíiha } \\ \text { 'his or her older } \\ \text { brother' } \\ \text { anyáac } \\ \text { 'his older } \\ \text { azcz }\end{array} \\ \text { 'his younger } & \begin{array}{l}\text { brother' } \\ \text { brother' }\end{array}\end{array}$

Female

Younger Older

atcz azáac

'her younger 'her older sister' sister'

acóome apáac

'his younger 'his older sister'

sister'

Seri does not have the kind of dynamic sound symbolism described for the neighboring Yuman languages (Langdon 1971), nor does it include a high degree of imitative words, although some vocabulary is obviously iconic. The vowels in the roots for 'large' and 'small' are open and close, respectively: -aacoj 'large', -isil 'small'. Certain roots relating to sounds 
include -pop 'pat', -oof 'blow (making "f " sound)', -oots 'sizzle (making "s" sound)', -anoj 'roar (like the sea), buzz (like bee)', -apláctim 'make slapping sound by hitting water or chewing loudly', -axax 'make a low or raspy or hollow sound', -ifáhzx 'make a short sobbing sound to indicate unhappiness', -iifz 'make snapping noise', -iipcö 'make thumping, pounding or muffled sound', -iisc 'make soft sound like when dragging foot on the ground', -iixaz 'make clacking or clinking sound', -iixöp 'make crunching sound; roar like ocean when the wind is blowing'. (Most of these are the intransitive stems, cited in the singular punctiliar form; the iterative or plural forms are slightly different, of course, as are the causative forms.)

A striking characteristic of the Seri lexicon is the dynamic, creative, uncontrived and selfsufficient way in which it expands to include new items. The lexicalized phrases are not a new thing in the language as they reflect a well-established pattern that has been used in the past to replace lexical items which have become taboo. Some examples: eenm an iquíijim 'mirror' (literally, metal in which one can see), eenm an iquíijim ziix cöimahnáxz 'glass, windshield' (more literally, 'mirror on which something has not been painted'), ziix iitax 'motor' ('thing with which it goes'), itj iixquim 'his/her belt' ('what s/he puts around his/her waist'), ziix iitax itj iixquim 'belt (of motor)', ziix iitax iyas 'battery (of car)' (literally, 'motor's liver').

\section{Phonological typology}

The phonological inventory of Seri is not particularly complex. It has four vowels, phonologically operating on a front-back and high-low system. Although it has a short-long vowel contrast, it does not have any of the laryngeal modifications typical of many other languages in Mexico. It is not tonal and does not have phonemic nasalized vowels. ${ }^{17}$

$$
\begin{aligned}
& \text { Vowel inventory } \\
& \begin{array}{clll}
\mathrm{i} / \mathrm{i} / & \text { ii } / \mathrm{ii} / & \mathrm{o} / \mathrm{o} / & \text { oo } / \mathrm{oo} / \\
\mathrm{e} / \varepsilon / & \text { ee } / \varepsilon \varepsilon / & \text { a } / \mathrm{a} / & \text { aa } / \mathrm{aa} /
\end{array}
\end{aligned}
$$

The consonants include eleven obstruents (all voiceless) and six sonorants (all voiced, except for the glottal stop, of course). The glottal stop is a significant consonant in the language and patterns phonotactically with the sonorants.

\begin{tabular}{|c|c|c|c|c|c|c|c|c|}
\hline bstruent inve & & & & & & & & \\
\hline Stops & $\mathrm{p}$ & $\mathrm{t}$ & & & $\mathrm{c}, \mathrm{qu}$ & cö & & \\
\hline & $/ \mathrm{p} /$ & $/ \mathrm{t} /$ & & & $/ \mathrm{k} /$ & $/ \mathrm{k}^{\mathrm{w}} /$ & & \\
\hline Fricatives & $\mathrm{f}$ & $\mathrm{s}$ & 1 & z & $\mathrm{j}$ & jö & $\mathrm{x}$ & xö \\
\hline & $/ \phi /$ & $/ \mathrm{s} /$ & $/ 4 /$ & $/ \mathrm{J} /$ & $/ \mathrm{x} /$ & $/ \mathrm{x}^{\mathrm{w}} /$ & $|x|$ & $/ \chi^{w}$ \\
\hline
\end{tabular}

\footnotetext{
17 Moser and Moser (1965) posited nasalized vowels, but the error in analysis was corrected about ten years later.
} Thus Seri should be removed from the sample cited in Ruhlen (1978). 


$\begin{array}{llllll}\begin{array}{llll}\text { Sonorant inventory } \\ \text { Nasals }\end{array} & & & & & \\ & \mathrm{m} & \mathrm{n} & & & \\ & / \mathrm{m} / & / \mathrm{n} / & & & \\ \text { Non-nasal }^{18} & & 1 & \mathrm{r} & \mathrm{y} & \mathrm{h} \\ \text { Resonants }^{18} & & / \mathrm{l} / & / \mathrm{r} / & / \mathrm{j} / & / \mathrm{l} /\end{array}$

The greatest complexity in the phonology of Seri is the syllable structure; the language permits (and frequently uses) syllables with two consonants in the onset, two or three vowels in the nucleus (one of them shorter and higher than the others), and two or three consonants in the coda. A few examples:

$$
\begin{array}{llll}
(87) & \text { ptcamn } & {[\text { ptkamn }]} & \text { 'lobster' (DS2005, ptcamn) } \\
(88) & \text { tpanzx } & {\left[\operatorname{tpan} \int \chi\right]} & \text { 'did s/he run?' (DS2005, cpanzx) } \\
(89) & \text { atcz } & {\left[\mathrm{atk} \int\right]} & \text { 'her younger sister' (DS2005, atcz) } \\
(90) & \text { itáaptxö } & {\left[\mathrm{i}^{\prime} \text { 'taapt } \chi^{\mathrm{w}}\right]} & \text { 'did s/he/it go through it?' (DS2005, caapto } \\
(91) & \text { coopxöt } & {\left[{\text { koop } \left.\chi^{\mathrm{w}} \mathrm{t}\right]}\right.} & \text { 'that which is loose' (DS2005, coopxöt) }
\end{array}
$$

Stress most commonly occurs on the first vowel of the root of a word, although in nouns there are numerous exceptions, probably due to compounding. While it is not always easy (perhaps never easy) to determine the exact underlying form of a root (because of the complexity involved with pluralization, as noted above), it is not difficult to identify the first vowel of the root.
Ihpyopánzx.
'I ran.'
(Stem: -panzx)
(93) Yopáncolxca. 'They ran repeatedly.'
(Stem: -pancolxca)
(94) hapáh
'what is put'
(Stem: $-a h)$
(95) hapáhtoj
'what are put'
(Stem: -ah-toj)

Primary stress occurs on the last constituent of a compound.

(96a) ziix cola hapáh 'thing that is put up high' (DS2005, ziix cola hapáh)

(96b) ziix cola hapáh 'flag' (pronounced somewhat faster than the phrase and with only one primary stress, at the end) (DS2005, ziix cola hapáh)

(96c) zixcolahapáh 'kite' (pronounced somewhat faster than the previous word and with no secondary stress at all) (DS2005, zixcolahapáh)

\footnotetext{
18 The lateral approximant is a very rare phoneme in Seri; the tap occurs only in loanwords.
} 


\section{References}

Abney, Steven P. 1987. The English noun phrase in its sentential aspect. Unpublished Ph.D. thesis, MIT, Cambridge, Mass.

Campbell, Lyle. 1997. American Indian languages: the historical linguistics of Native America, Oxford: Oxford University Press.

Farrell, Patrick; Stephen A. Marlett, and David M. Perlmutter. 1991. Notions of subjecthood and switch reference: evidence from Seri. Linguistic Inquiry 22:431-56.

Langdon, Margaret. 1971. Sound symbolism in Yuman languages. In Jesse O. Sawyer (ed.), Studies in American Indian Languages, University of California Publications in Linguistics 65, pp. 149-173.

Marlett, Stephen A. 1981. The structure of Seri. Unpublished Ph.D. thesis. University of California, San Diego.

----- 1984a. Personal and impersonal passives in Seri. Studies in relational grammar 2, 217-239, ed. by David M. Perlmutter and Carol Rosen. Chicago: University of Chicago Press.

----. 1984b. Switch-reference and subject raising in Seri. Syntax and semantics 16: the syntax of Native American Languages, 247-68, ed. by E.-D. Cook y D. Gerdts. New York: Academic Press.

----. 1988. The syllable structure of Seri. International Journal of American Linguistics 54.24578.

----- 1990. Person and number inflection in Seri. International Journal of American Linguistics 56:503-541.

----- 2000. Quantification with 'all' in Seri. Work Papers of the Summer Institute of Linguistics, University of North Dakota Session, vol. 44. [www.und.nodak.edu/dept/linguistics/wp/2000Marlett.PDF].

-----. 2001. La relación entre lenguas "hokanas" en México: ¿Cuál es la evidencia? Presentation at the III Coloquio Swadesh, Universidad Nacional Autónoma de México, Instituto de Investigaciones Antropológicas, México, D.F. (Currently in press, UNAM.)

-----. (submitted for publication) La evolución del alfabeto seri. Paper presented to the VIII Encuentro Internacional de Lingüística en el Noroeste, Hermosillo, Sonora, November 17-19, 2004.

Marlett, Stephen A.; F. Xavier Moreno Herrera and Genaro G. Herrera Astorga. 2005. Seri. Journal of the International Phonetic Association 35.1: 117-121.

Marlett, Stephen A. and Mary B. Moser. 1989. Terminología de parentesco seri. Anales de Antropología 26: 367-88. México: UNAM.

-----. 1994. El desarrollo de clases nominales en seri. Estudios de Lingüística y Sociolingüística, ed. by Gerardo López Cruz and José Luis Moctezuma Zamarrón. Hermosillo: Universidad de Sonora and Instituto Nacional de Antropología e Historia.

----- 1994. Los números en seri. II Encuentro de lingüística en el noroeste, memorias, II:63-79, ed. by Zarina Estrada Fernández, Departamento de Letras y Lingüística, División de Humanidades y Bellas Artes, Universidad de Sonora, Hermosillo. Published on-line (1997): Los números en seri. SIL Electronic Working Papers 1997-005. [http://www.sil.org/silewp/1997/005/]

-----. 2000. Polar questions in Seri. Work Papers of the Summer Institute of Linguistics, University of North Dakota Session, vol. 44. [On-line: http://www.und.nodak.edu/dept/linguistics/wp/2000Marlett-Moser.PDF] 
Moser, Edward W. 1961. Number in Seri verbs. Master's thesis, University of Pennsylvania.

Moser, Edward W. and Mary B. Moser. 1965. Consonant-vowel balance in Seri (Hokan) syllables. Linguistics 16: 50-67.

-----. 1976. Seri noun pluralization classes. Hokan studies, ed. by Margaret Langdon and Shirley Silver. The Hague: Mouton, 285-96.

Moser, Mary B. 1978a. Switch-reference in Seri. International Journal of American Linguistics 44: 113-120.

-----. Articles in Seri. 1978b. Proceedings of the 1977 Hokan-Yuman Languages Workshop, University of Utah, June 21-23, 1977. Occasional Papers on Linguistics 2. Carbondale, IL: Southern Illinois University, 67-89.

Moser, Mary B. and Stephen A. Marlett. 1993. Seri kinship terminology. Work Papers of the Summer Institute of Linguistics, University of North Dakota Session 37: 21-35.

Moser, Mary B. and Stephen A. Marlett, compilers. 2005. Comcáac quih yaza quih hant ihíip hac: Diccionario seri-español-inglés. Hermosillo, Sonora: Universidad de Sonora and Plaza y Valdés Editores.

Nichols, Johanna. 1986. Head-marking and dependent-marking grammar, Language 62:1, 56119.

Ruhlen, Merritt. 1978. Nasal vowels. Universals of human language, ed. by Joseph H.

Greenberg, Stanford: Stanford University Press, pp. 203-241. 